\title{
Sowing the Semillas of Critical Multicultural Citizenship for Latina/o Undocumented Youth: Spaces in School and out of School
}

\author{
Maria del Carmen Salazar \\ University of Denver \\ U. S. A. \\ Lisa M. Martinez \\ University of Denver \\ U. S. A. \\ Debora Ortega \\ University of Denver \\ U. S. A.
}

ABSTRACT: The purpose of this study is to address how spaces in school and out of school support or constrain undocumented Latina/o youths' development as critical multicultural citizens. We draw on data from a multi-phase, qualitative study to present findings indicating that the youths persevered through academic and civic engagement. Ultimately, the students drew from their liminal status-the space between legal and "illegal"-to become stewards of a cause. The analysis is limited to a subset of data on undocumented participants from a larger study of the pathways to mobility among Latina/o youth.

\section{KEYWORDS: Latina/o, undocumented, citizenship, in-school, out-of-school}

\author{
Context \\ Theoretical Framework \\ Methods \\ Results \\ Conclusion \\ References \\ Author Contact
}

Every day across the U.S., undocumented Latino/a youth are systematically disenfranchised, marginalized, and deprived of basic human rights. Moreover, they are branded as "aliens" who are undeserving of citizenship. As a result, undocumented Latina/o youth live along the margins of U.S. society. Hooks (2000) writes about "choosing the margins as a space of radical openness" (p. 203). While undocumented youth do not choose to live in the margins of U.S. society, they discover their power in its fragmented spaces. The undocumented Latina/o participants in our study epitomize a Mexican 
proverb, "Quisieron enterrarnos, pero se les olvido que somos semillas." The proverb is translated as, "They tried to bury us, but they forgot we are seeds." The undocumented Latina/o students highlighted in this study demonstrate their resilience even as they feel buried under structural inequalities in the U.S. schooling system and society. This study illustrates how the seeds for critical multicultural citizenship can be sowed in spaces inside and outside of school.

\section{Context}

Undocumented immigrant youth are a growing proportion of the U.S. population. Reports suggest nearly 12 million undocumented immigrants are living in the United States (Passel \& Cohn, 2011) and 1.8 million of these are children (Gonzales, 2007). Moreover, in 2014, it was estimated that approximately 60,000 unaccompanied, undocumented minors ranging from ages 5-17 crossed the border (Valdes, Valencia, \& Levs, 2014). In some states, children of immigrants--both foreign-born and U.S. citizens--account for approximately $10 \%$ of $\mathrm{K}-12$ student populations, and the numbers are expected to grow. This relatively young immigrant population (Passel \& Cohn, 2011) will comprise a significant proportion of elementary and secondary school populations in the next several decades (Gildersleeve \& Hernandez, 2012).

Due to their status, Latina/o undocumented youth face formidable challenges along the educational pipeline in the U.S. Latina/o students have been "compelled for generations to divest themselves of their linguistic, cultural, and familial resources to succeed in U.S. public schools" (Salazar, 2013, p. 121). The educational goal for Latina/o students is often assimilation into mainstream values and practices. They are expected to "act, speak, and behave as much as possible like the White middle class" (Warikoo \& Carter, 2009, p. 374). As a result, they are stripped of the cultural resources they need to survive and thrive in the educational system and in U.S. society (Salazar, 2013).

Furthermore, Latina/o students are denied opportunities for learning (Gandara \& Contreras, 2009). Statistics show that Latina/o students are the most segregated student population in the schools. In the western United States, "60 percent of Latinos in the large cities attend hyper-segregated schools in which 90 to 100 percent of students are non-White" (Gandara \& Contreras, 2009, p. 4). Moreover, undocumented Latina/os have less access to quality schooling; thus they are less likely to be enrolled in college prep tracks in high school (Hill \& Torres, 2010). As a result of their (mis)education (Nieto, 2009), it is estimated that $40 \%$ of undocumented students drop out of high school (Perez, 2014). For those arriving at age 14 or older, the estimates are even higher, approximately 46\% (Perez, 2014). Additionally, Oliverez, Chavez, Soriano, and Tierney (2006) state that approximately 65,000 undocumented students graduate from high school every year, with only 5 to $10 \%$ of those going on to attend some form of higher education (Gonzales, 2007). 
Similarly, undocumented youth face staggering obstacles outside of school (Abrego, 2006; Abrego \& Gonzales, 2010; Gonzales \& Ruiz, 2014). Menjívar (2006b) contends that the interplay of social and political forces impinges upon immigrants' lives in myriad ways. These include sociolegal forces that affect their inclusion or expulsion from the country (Dingeman-Cerda \& Rumbaut, 2015). Abrego (2006) and Menjívar (2006a; 2006b) indicate that the sociolegal contexts linking immigration laws and policies to access to education contribute to liminal spaces inhabited by undocumented immigrants that render them neither legal nor "illegal." This liminal legality can extend for indefinite periods of time (Menjívar, 2006b). It accounts for how undocumented youth may access certain resources available to citizens, such as access to education in K12, but be denied others such as access to financial aid to attend institutions of higher education. Additionally, Juan Crow laws, policies, and practices across the United States have been developed to deter illegal immigration and relegate the undocumented to (non)citizenship (Romero, 2014). For example, "show-meyour-paper laws" make it illegal to be illegal.

Federal immigration policies such as Deferred Action for Childhood Arrivals (DACA) and Deferred Action for Parental Accountability (DAPA) provide opportunities for undocumented youth and their parents, but still fall short of granting citizenship and full access to the rights and privileges of native-born citizens, including access to higher education. With blocked paths and limited opportunities, undocumented youth may remain a permanent underclass, even at a time of greater access to education (Abrego, 2006; Abrego \& Gonzales, 2010; Gonzales \& Ruiz, 2014).

The purpose of this study is to address how in-school and out-of-school experiences support or constrain undocumented Latina/o youth's development as critical multicultural citizens. We draw on data from a multiphase, qualitative study of Latina/o undocumented youth to address the following question: What are the factors inside and outside of school that support or constrain Latina/o undocumented youth's development as critical multicultural citizens? The analysis is limited to a subset of data from a larger study of the pathways to mobility among Latina/o youth, focusing here on the undocumented participants in our study.

\section{Theoretical Framework}

Undocumented Latina/o youth are often characterized as the antithesis of a citizen. They are impossible subjects, or "illegal aliens whose inclusion in the nation is a social reality but legal impossibility" (Ngai, 2014). The use of the term "alien" implies that they are not human and thus can be denied basic human rights afforded to "citizens." The section that follows presents literature that describes notions about citizenship and multicultural citizenship education. 


\section{Notions of Citizenship}

Current immigration laws and policies are leading to "citizens of nowhere." The concept of "citizens of nowhere" is used to describe persons who do not have the recognition or protection from any country (United Nations High Commissioner for Refugees [UNHCR], 2012). Such individuals face discrimination and abuse and are often denied the most basic of human rights. Mydans (2007) asserts that without citizenship, citizens of nowhere are often the "most vulnerable segments of humanity" (para. 1).

The idea that Latina/o undocumented youth are citizens of nowhere aligns with Anzaldua's (2012) notion of Nepantla, an Aztec word meaning torn between ways. Nepantla is a state of in-betweenness that represents a sense of rootlessness for undocumented youth who are neither tied to their country of origin, nor the country of reception. As a result, undocumented Latina/o youth are ni de aquí, ni de allá, neither from here, nor from there (Franquiz \& Salazar, 2007). Educational scholars have documented the experiences of Latina/os caught between two worlds, thus, experiencing spaces of tension, hybridity, and ultimately, liberation that can foster the development of complex and nuanced forms of citizenship (Anzaldua, 2012; Franquiz \& Salazar, 2007; Franquiz, Salazar, \& DeNicolo, 2011; Ortiz, 2013; Salazar, 2013)

Castro (2012) identifies three forms of citizenship: traditional, participatory, and critical. Traditional forms of citizenship emphasize conformity to the status quo through a focus on values such as self-sacrifice, patriotism, and loyalty (see also Knight Abowitz, \& Harnish, 2006). Such traditional notions are rooted in American folklore that emphasizes the importance of good character, individualism, and personal responsibility. This form of citizenship inculcates the message that citizenship encompasses voting and following laws. Traditional forms of citizenship education exclude undocumented youth who are denied the right to vote and criminalized by their mere presence in the U.S. Critics of traditional forms of citizenship stress that this approach promulgates obedience to authority and discourages questioning inequitable societal practices (Banks, 2008; Castro, 2012).

Second, participatory forms of citizenship encourage citizens to act as agents for community improvement by solving local problems (Castro, 2012). This form of citizenship includes (a) a commitment to resolving local problems, (b) the development of leadership skills that build one's capacity to solve problems, and (c) working collaboratively with others to accomplish change (Castro, 2012; Westheimer \& Kahne, 2004). Critics of participatory forms of citizenship underscore the fact that this approach is often colorblind (Castro, 2012). In reality, the focus of participatory citizenship is often on the "whitestream culture" (Urrieta, 2004). Additionally, this approach often becomes "fairy-tale-like-citizenship" (KnightAbowitz, \& Harnish, 2006) that avoids 
controversial issues and turns a blind eye to oppression, in favor of issues that promote consensus and harmony.

Lastly, justice-oriented forms of citizenship transpire from the interrogation of social, political, and economic structures that reproduce injustice (Westheimer \& Kahne, 2004). Using a critical lens to examine inequities leads to social action that interrupts injustice (Boyle-Baise 2003; Castro, 2009). This form of citizenship identifies the systemic origins of structures that limit the development of citizenship based on gender, culture, language, race, socioeconomic status, and undocumented status, to name just a few (Boyle-Baise, 2003). Apple and Beane (2007) stress that justice-oriented citizenship can lead to change in the conditions that produce social inequity. Justice-oriented citizenship is deemphasized in schools in favor of traditional and participatory education (Castro, 2012; Swalwell, 2013). However, Westheimer and Kahne (2004) assert that justice-oriented citizenship is essential for the creation of a more robust democracy.

\section{Critical Multicultural Citizenship Education}

Critical multicultural citizenship education is justice-oriented. The goal of critical and multicultural citizenship is to create a just society through social action (Castro, 2009, Dilworth, 2004). According to Castro (2013), there are three tenets of critical multicultural citizenship education.

First, critical multicultural citizenship education "seeks out and challenges gaps between the rhetoric of democracy and realization of democracy" (Castro, 2012, p. 33). Such gaps include valuing cultural diversity, the struggle for social justice, and institutional barriers. Moreover, critical multicultural citizenship education requires awareness of injustice, including the ways in which institutional structures construct barriers to a more democratic society (Castro, 2012, p. 4).

Second, critical multicultural citizenship education promotes critical consciousness (Castro, 2012). This consciousness is prompted by critical reflection and dialogue. A dialogic approach supports the development of critical consciousness, which is "learning to perceive social, political, and economic contradictions, and to take action against the oppressive elements of reality" (Freire, 1970, p. 17). As such, the development of critical consciousness "gives the oppressed access to their consciousness and gives voice to their consciousness" (Alexander, 2002, p. 112).

Third, critical multicultural citizenship education stimulates collective action with the aim of challenging inequities and transforming institutional structures that reproduce inequality and injustice (Castro, 2012). Robertson (2008) defines collective action, or activism, as "employing strategies of mobilization, protest, and disruption that call attention to a particular cause or current injustice" (p. 4). Freire (1970) emphasizes that action and reflection occur simultaneously and 
can potentially transform structures that impede humanization and facilitate liberation. Freire (1970) insists that the oppressed must name their own oppression so that they can disrupt inequity and demand social change. Thus, critical multicultural citizenship challenges students to critically engage with the world so they can act on it (Giroux, 2010).

\section{Methods}

The data for this analysis stem from a larger study of the educational and occupational trajectories of 60 Latina/o youths. Using a snowball sampling method, we recruited youths between the ages of 16 and 26 from high schools, community colleges, and 4-year institutions of higher education. We also recruited participants through contacts in the immigrant rights movement. Our sample includes youths who were pre-college age, college age, and post-college age, as these time points enabled us to capture respondents at key moments across their educational trajectories. We employed a semi-structured interview format to gauge respondents' experiences in the K-12 pipeline and beyond.

Of the 60 participants, 18 self-identified as undocumented. Almost all of the 18 respondents were born in Mexico; two were from Central America. All had migrated to the United States before the age of 10, making them part of the 1.5 generation (Rumbaut, 2004). Of these respondents, 13 were female and 5 were male; they ranged in age from 19 to 26 . At the time of the interviews, nine were attending a four-year college or university, four were attending a community college, three had graduated from college and were employed, and two had briefly attended college before withdrawing. The majority of respondents lived in mixed-citizenship households where at least one family member, usually a younger sibling, was a citizen. All but two respondents had applied for or received Deferred Action. In keeping with IRB protocols, all names are pseudonyms.

We analyzed the data for the 18 undocumented participants and purposefully selected six participants. Of the six participants, all were born in Mexico, three were male and three were female, and their age range was 19-26. All but one was in college or had graduated from college. One respondent had some college, but was not attending at the time of the interview for financial reasons. The participants were selected because they most fully exemplified the tenets of critical multicultural citizenship. Specifically, the six who were selected displayed an enacted sense of critical multicultural citizenship, while the remaining 12 could be classified as emerging or latent. Participants with an enacted sense of critical multicultural citizenship displayed evidence of all three tenets (awareness of injustice, development of critical consciousness, and action toward the collective good). Participants with emerging critical multicultural citizenship demonstrated the development of two tenets (e.g., awareness of injustice, development of critical consciousness). Participants with latent critical 
multicultural citizenship demonstrated the development of one tenet (e.g., awareness of injustice).

The construction of the project, the method of analysis, and the reporting of results entail the use of testimonios (testimonies), the objective of which is to bring to light a wrong, a point of view, or an urgent call to action. As Albert and Couture (2014) note, testimonios signify an act of bearing witness in the legal or religious sense, the aim of which is to present a person as a representative of the collective. Testimonios are reflections that are often spoken; they are intentional and political and are a way of naming oppression. Used by Chicana scholars, for example, "testimonios are the means by which agents of knowledge can speak to oppression and empower oppressed people" (as cited in Collins, 1991, p. 220). They are awakenings for tellers and readers alike (Reyes \& CurryRodriguez, 2012). We use testimonios in our analysis of the interview data to bring to light the wrongs experienced by undocumented students, to share their points of view, and as a call to action.

Research rooted in testimonio necessitates a grounded theory approach to data analysis. The researchers individually analyzed each transcript identifying quotations that reflected facilitators and barriers to educational success. The critical multicultural citizenship construct emerged from the narratives of these successful educated and undocumented Latinos/as. The researchers witnessed three emerging themes that described the process toward critical multicultural citizenship. These were coded as awareness of injustice, development of critical consciousness, and action toward the collective good. These themes are exemplified in each of the narratives that are presented below.

\section{Results}

In our study, the respondents' testimonios speak to the central tenets of critical multicultural education. As the narratives below show, respondents recognized gaps in the rhetoric and realization of democracy, they developed critical consciousness in challenging the status quo for themselves and others, and they worked to transform institutional structures in school and out of school (Castro, 2012; 2013). We also show how the seeds of critical multicultural citizenship were sowed in spaces inside and outside of school.

\section{Maria}

Maria (age 25) migrated to Colorado with her family who came in search of a better life. They left Mexico for the United States when she was just 9 years old. One of her earliest memories in school was a teacher telling her she was never going to get an A in English class because her English was not good 
enough. She recalls, "I remember I didn't say anything, I just walked back and sat in my seat and obviously I was humiliated, and I felt really sad."

Once in high school, Maria became active in school activities at her mentor's urging. It was in her ESL classroom that she became interested in extracurricular activities that focused on social activism. She recalled how a group of Latina/o students attended her ESL class and asked their peers to join the school's climate committee. At first, Maria was apprehensive about participating on the committee; however, her mentor encouraged her by saying, "You have to be brave. You have to do these things." She added, "I always remember that whatever I was doing, it wasn't just for me. It was for me and other Latina students. I'm going to do this because this is better for us and this is good for the Latino community at our school."

Maria continued to be civically involved once she entered a local community college. Because she was undocumented, she was unable to find work without a social security number, but she had done some work with a local nonprofit dedicated to social justice in her community. Maria began organizing, which she continued to do after transferring to a four-year university. She stated, "I want to do something that has to do with politics or social issues, helping people."

Maria was able to develop critical multicultural citizenship due to the support of a mentor in high school, the opportunity to get involved with issues that were important to her in school, and finally through her work with a civic organization outside of school. Once developed, she had the tools to question systems of inequality that affected her and other undocumented students.

\section{Ruben}

Ruben (age 19) became involved in immigrant rights organizing while he was a junior in high school. Growing up in a small town, Ruben never had much exposure to activism until he met a local immigrant rights organizer. As he shared, the individual and the entire organization took him under their wing and "really opened my eyes to a lot of things." As an undocumented high school student, he was drawn to the organization that engaged in actions in support of the DREAM Act. He recounted:

I met [the organizer] and we actually decided to make a DREAM Act rally in [town] where we had over 200 people holding up signs about the DREAM Act. I got really into the movement. So myself and two other friends decided to make an assembly at our high school where we would openly share stories of being undocumented, and we invited the whole school. From there we started a student group. So now I'm an organizer for the organization. I've been way more open about being undocumented and not ashamed or scared to tell people about it. 
Meeting the community organizer spurred Ruben to consider what his activism meant for him, his brother, and their parents. As Ruben recalled, "It's not just about me, it's about my family. What if my brother or parents get picked up because l've been openly speaking about it?" Ruben was also aware of the opportunities he had missed out on because of his status. He recalled an example where he was invited to visit the White House in Washington, D.C. for a leadership training program. Ruben was unable to attend because his parents feared he would not be able to travel without papers. He said, "I remember that was a big blow, because I didn't have papers I couldn't do it."

Ruben became the student body president in high school. It was this leadership position that gave him the confidence to organize multiple assemblies where he and others would discuss important social issues. Ruben recalled the assembly where he discussed immigration and the experiences of undocumented students. He also recalled how this experience had a positive impact by increasing teacher and peer support for the undocumented youths.

Despite his confidence and support for other undocumented students, Ruben had moments where he doubted his own path. He stated,

There's not a year in high school where I didn't think about dropping out. And that's something we came to realize in the student organization. It turns out that all of us at least once a year thought about dropping because we wouldn't know what our future was. If we couldn't go to college, we knew we could apply and apply for scholarships, I mean what's next? We just get a degree and go back to Mexico with little Spanish or no español mucho (Spanish much).

He also explained how at times he felt "a little bipolar." He described being involved in pre-collegiate programs where he was receiving support to go to college, yet also dealing with issues because of his status.

Additionally, Ruben challenged the approach to Deferred Action for Childhood Arrivals. He stated,

I saw the state of the union address and Obama said that people would have to go to the back of the line for people who were trying to do it the right way once again. I remember going on Facebook and posting a picture about Rosa Parks about how in the 1950s she was told to go to the back of the bus and now we're being told to go to the back of the line. There's also so many of us that have been helping the United States with our labor that we shouldn't be thrown to the back of the line.

Ruben expressed that he hoped to graduate with a bachelor's degree and return to his community to teach history. But he was not interested in teaching just any history. He stated,

I think one of my goals is teaching the history that never gets taught, so I think of going back to Cesar Chavez and Martin Luther King, since we're talking about civil rights and stuff like that, I just think about immigration issues and stuff like that that I never got taught in school, I had to learn 
through the people in [the immigrant rights organization] and through myself. That's sort of one of my goals, since I'm going to teach history, not the white history.

Ruben developed critical multicultural citizenship based on his interactions with an activist who helped him feel passionate about fighting for civil rights inside and outside of school. Moreover, he was able to take leadership positions in school that galvanized him to strive for social change. This commitment to social justice in school blossomed into activism in the community on behalf of undocumented students.

\section{Lupe}

Lupe (age 20) had a circuitous path to activism. A star student from an early age, she received a scholarship to attend a prestigious private middle and high school. Feeling alienated by her peers at school because of differences along the lines of race/ethnicity, social class, and citizenship, Lupe was introduced to and became immersed in gang life outside of school alongside her cousins. After some time, she realized gang life was not for her and, after the untimely death of a cousin, she decided to leave it behind and return her focus on her schooling. For Lupe, the way out began with learning about her history through a program in her community geared toward supporting gang involved youth. Lupe commented,

So when I got to [the youth program], the first thing they told me was that we're all interconnected. He [the director of the program] starts telling me about my history. "Your people, you come from warriors, you come from kings, you come from royalty." I never learned this. It just gave me a whole different perspective about humanity and something that I didn't know. And by giving me a little lesson in the history of my people it was such a changing thing.

Lupe's passion for activism grew stronger towards the end of high school, when the challenges of being undocumented became more palpable. After being awarded a scholarship and having it taken away because she did not have a social security number, Lupe became even more involved in the immigrant rights movement. She participated in sit-ins, protests, and hunger strikes outside President Obama's campaign headquarters before the 2012 election. She proudly shared, "I was one of those students sitting outside sleeping in the street! And off of that we launched many other [protests] throughout the country." Deferred Action had just been announced in the midst of protesting. Despite having the option, Lupe delayed applying for DACA because she was afraid to share information about herself with the government out of fear that it was a ploy to get undocumented immigrants to out themselves. For Lupe, the reality was bittersweet, she noted: 
I cried so much because I had been denied so many opportunities for my numbers...that little card denied me of so many things and it's frustrating. It's like a bittersweet feeling that I finally have this stupid little card. I see it in a completely different light now. I value it like you have no idea.

Once she got over the initial fear, Lupe began thinking about possibilities and how to use her new status to help others. Like many of our respondents, she contemplated how best to help others. She described how she hoped to start a non-profit organization where youth would have a space to focus on the arts, writing, and spoken-word. She stated, "I feel that's what I want my place to be, to provide resources for DREAMers like me."

Lupe's influence was felt in the immigrant rights community, and she was leaving a mark on her younger brother, a U.S. citizen. She proudly shared how, as a $3 r d$ grader, he wrote a report on the need for comprehensive immigration reform. Lupe also recounted how her brother wrote an article for a class assignment about why his name was Juan, not John.

Lupe's critical multicultural citizenship was incited while she was in high school in response to her feeling of isolation at school and the lack of opportunities she faced outside of school. As she realized that her heritage, history and culture had been denied to her, the seeds of critical multicultural citizenship took root. An activist while in college, she planned to eventually start a nonprofit where other students like her could find support.

\section{Moises}

Moises (age 26) worked for a social justice organization to support youth of color. Moises joined the organization at the end of his sophomore year in high school after being prompted to attend a meeting by friends. Moises recalls wanting to be part of a solution. He began working on collecting data on students who were getting pushed out of school. Later, he began working on the DREAM Act where he participated in actions and rallies, which then evolved to challenging his teachers. Moises explained:

I knew we weren't being prepared. At times you kind of lose hope. You're not worth anything. I started challenging my own teachers. It was all through organizing and really understanding that I am someone. It gave me strength. It gave me a vision for what I wanted for my life.

Prior to joining the organization, Moises described himself as a disengaged student who felt "hopeless," which he largely attributed to his undocumented status. He admitted, "I just had a feeling of not caring anymore. I limited my dreams." Like many undocumented youth, Moises lost the drive and motivation to succeed in school as he saw limited opportunities on account of his status. Getting involved in his community helped him to find a purpose. Moises experienced many victories and some difficult defeats in his work with the organization. Still, he was proudest of the work he had done in support of the 
DREAM Act, which allowed him to engage with local elected officials and to testify before state legislators.

After a discussion about DACA, Moises reflected on his experiences and offered insights into what he saw as the remaining, pressing issues for social justice activists working on behalf of undocumented immigrants. He stated, "Anyone who works in a school has a responsibility to change school culture. They're going to change things for those students that felt hopelessness." He added that communities of color need to be empowered to participate in the democratic process, stating:

We need to empower anyone that can vote to vote. This is a political game. There's a reason why things are proposed as they are and it's to disengage and disempower a community. We have to seize the moment and make sure we let them know that they just can't disenfranchise black and brown people like that. We're not just gonna be left out of this game. We'll just keep fighting... power is born out of struggle...

Moises developed critical multicultural citizenship in his K-12 experience as a result of the education he received outside of school in activist organizations. This caused him to challenge the gaps in his schooling and develop consciousness of systematic oppression and suppression of human rights. Even though undocumented students had made some gains in the form of DACA and state-level tuition measures, Moises continued his fight against systemic inequities.

\section{Ricardo}

Ricardo (age 21) was a junior in college majoring in business. He described himself as having "a goal-oriented or education-oriented mentality." Ricardo attributed his success to a leadership program in high school for Latina/o youth. In particular, the program taught him about youth empowerment, the value of academics, and the importance of Latina/o history.

Once in college, Ricardo became civically engaged at the urging of a professor who encouraged him to intern with a Latina/o non-profit organization. As luck would have it, the internship supervisor had once worked for a foundation dedicated to under-represented and lower income youth getting college scholarships. Ricardo received a scholarship, which would allow him to transfer to a university that had long been his top choice of school. The internship paid off in other ways; he became involved in politics, learning about legislative redistricting, legislative reapportionment, and public policy work. Once at his new school, Ricardo wasted little time in getting involved on campus, joining organizations and, later, running for student body president. The latter proved to be an issue, however, as it was a paid position and, without a social security number, Ricardo was ineligible. Just when he thought it would not be possible, he learned about DACA. He shared, "I think now especially with deferred action 
being able to work and having a social security number, the opportunities are limitless."

Ricardo had the opportunity to learn about his culture and engage in a high school organization that stressed empowerment. This led him to a trajectory to develop leadership and take a stand for immigration issues. Unlike the other respondents, Ricardo felt he could bring about the most change by working within institutions, but the goal was nonetheless the same: to provide limitless opportunities for undocumented youth.

\section{Tania}

Tania (age 23) also recounted how her interest in civic engagement began in high school. Among her activities was starting a club for Latina/o and "underprivileged" students. She also took an interest in leadership opportunities at school and sought out programs that involved community service.

Once in college, Tania identified herself as undocumented, and she started a support group for other undocumented students. Tania had long been interested in immigrant rights organizing, but being one of only a few undocumented students at her university who were "out" compelled her to become more engaged in the movement. Once she transferred to another university where she met other undocumented students, she saw an opportunity to fill a gap, as little was being done in support of undocumented students. She and a group of peers became involved on campus. She stated, "I started really talking to my teachers and talking to other people and doing panels and having educational pieces, movie showings, and tabling outside the cafeteria. Just to bring awareness of the issue of the DREAM Act."

Tania was active in social justice campaigns in support of in-state tuition for undocumented youth and comprehensive immigration reform while simultaneously fighting her mother's deportation order. At the time of the interview, she was working for a social justice organization and had only recently applied for DACA. The decision to delay her application was a personal and political one; she helped her brother apply but held off given her mother's situation. Thus, even though DACA would have created new opportunities for her, Tania's commitment to social justice meant waiting and working to improve the lives of those ineligible for DACA such as her mother.

\section{Conclusion}

As Apple and Beane (2007) and Swalwell (2013) argue, justice-oriented citizenship not only produces good community members, it produces good citizens who work to change the conditions that produce inequality. This is embodied through understanding structural inequalities and forms of injustice, 
developing critical consciousness, and engaging in actions that bring about change for a more just society.

Respondents' testimonios speak of barriers both in school and out of school-factors ranging from teachers doubting them to negative peer influences and allies who lost sight of the importance and goals of the immigrant rights movement. Despite and often because of the challenges, they found ways to channel their energy into activism, toward issues that affected them and others as well. Moreover, the participants discovered critical multicultural citizenship education spaces inside and outside of school that supported their development as critical multicultural citizens including access to extracurricular activities, mentors, and civic organizations. Thus, the seeds of critical multicultural citizenship for Latina/o undocumented youth were sowed in school and out of school via mentors, social justice advocates, and students' own critical consciousness. These factors put them on a path toward critical multicultural citizenship, which was enacted by and through their activism. Although respondents' status presented many personal, legal, and structural challenges, they were resolute in working toward a more just society, even one that denies them citizenship through its laws, policies, and practices (Valenzuela \& Brewer, 2011; Romero, 2014).

As Castro (2012; 2013) argues, the goal of critical multicultural citizenship education is to create a just society. Respondents noted key moments in school and out of school when they first encountered opportunities to fill the gaps between democratic principles and the realization of democracy. This entailed valuing diversity and an ardent commitment to raising awareness about barriers and removing barriers. They also developed and promoted critical consciousness to address social, political, and economic contradictions, contradictions that affected them and those around them (Alexander, 2002). What resulted was collective action and activism geared toward naming their oppression and disrupting structural inequities (Freire, 1970).

As the narratives show, the respondents in this study were high-achievers. Identified by teachers at an early age, they participated in programs and activities typical for college-bound youth; nevertheless, because of their status, they were unable to fully enjoy the benefits of their academic credentials. Many faced their first blocked opportunities in high school as the realities of not having a social security number set in, and their goals, hopes, and dreams were dashed. Yet, the youths persevered by finding ways to not only remain academically engaged but civically engaged as well. Furthermore, because of their liminal status-the space between legal and "illegal"- -they learned to be stewards of a cause. Ultimately these youths became citizens for a cause rather than citizens from nowhere. They were guided by the recognition of the challenges they faced, consciousness of systemic oppression, and a desire for social justice through actions that supported la causa (the cause) of human rights for the undocumented.

The findings are more than witnesses to narratives of injustice; they also provide lessons for those working with Latina/o youth in schools, including 
teachers, administrators, and counselors along the P-16 pipeline. Educators can glean important insights from the findings in this study and translate this into practices that support undocumented youth. First, supporting Latina/o students necessitates personal awareness and understanding of the tribulations of immigration policies for undocumented youth and their families. Understanding the context of immigration can give educators a greater understanding of the challenges that undocumented students navigate on a daily basis. Second, it is vital that educators challenge the undocumented students academically and provide access to high-level learning through advanced and college-bound programming. Third, it is essential to engage undocumented youth not only academically, but also civically. The youth in this study were able to maintain hope, even while they were faced with challenges that would cause most to experience despair. Keeping the youth connected to a greater cause helped them to experience a sense of belonging and empowerment. Lastly, educators must not lose sight of the humanity of the undocumented students, who are often invisible or marginalized in U.S. society.

Our study also provides lessons for allies and stakeholders outside of school. As each of the narratives reveals, undocumented youths benefit greatly from the influence and support of mentors and allies. First, allies outside of school can transform youths' lives and experiences using cultural tools that resonate with the youths. This includes teaching them about the history and contributions of people of Latina/o origin; recruiting them to participate in out-ofschool social justice organizations; and inculcating them with the leadership, public speaking, and organizing skills that empower them to bring about change in their communities. Thus, the youth can maintain and develop their cultural and civic identities. Second, allies can provide a safe and welcoming environment outside of school in order to embrace the humanity of undocumented youth, provide a space for connectivity, and create a forum for sharing successes and challenges. Third, allies can support the issues that are near and dear to undocumented students and their families.

Negative and positive experiences inside and outside of school create spaces where Latina/o undocumented youths develop critical multicultural citizenship, a citizenship devoid of nations, borders, or boundaries. The narratives of the undocumented youths' in this study speak to the ways in which they participate in the social and political life of the United States. Even though they lacked citizenship in the legal sense, they exemplified citizenship in the civic sense through their commitment to civil rights for all of the nation's people.

\section{References}

Abrego, L. J. (2006). "I can't go to college because I don't have papers": Incorporation patterns of Latino undocumented youth. Latino Studies 4(3), 212-231. 
Abrego, L. J., \& Gonzales, R. G. (2010). Blocked paths, uncertain futures: The postsecondary education and labor market prospects of undocumented youth. Journal of Education for Students Placed at Risk, 15(1), 144-157.

Albert, M. N., \& Couture, M. M. (2014). To explore new avenues: Experiential testimonio research. Management Decision, 52(4), 794-812.

Apple, M., \& Beane, J. (2007). Democratic schools: Lessons in powerful education $\left(2^{\text {nd }}\right.$ ed.). New York, NY: Heinemann.

Alexander G. C. (2002). Interactive management: An emancipator methodology. Systematic Practice and Action Research, 15, 111-122.

Anzaldua, G. (2012). Borderlands/La frontera: The new mestizo. (4th ed.). San Francisco, CA: Aunt Lute Books.

Banks, J. A. (2008). Diversity, group identity, and citizenship education in a global age. Educational Researcher, 37(3), 129-139.

Boyle-Baise, M. (2003). Doing democracy in social studies methods. Theory \& Research in Social Education, 31(1), 51-71.

Castro, A. J. (2009). Promoting critical multicultural citizenship: A case study of preparing social studies teachers. Unpublished dissertation, University of Texas at Austin, Austin, TX.

Castro, A. J. (2012). Challenges in teaching for critical multicultural citizenship: Student teaching in an accountability-driven context. Journal of Action in Teacher Education, 32(2), 97-109.

Castro, A. J. (2013). What makes a citizen? Critical and multicultural citizenship and preservice teachers' understanding of citizenship skills. Theory and Research in Social Education, 41(2), 219-246.

Collins, P. H. (1991). Black feminist thought: Knowledge, consciousness, and the politics of empowerment. New York, NY: Routledge.

Dilworth, P. P. (2004). Multicultural citizenship education: Case studies from social studies classrooms. Theory \& Research in Social Education, 32(2), 153-186.

Dingeman-Cerda, K., \& Rumbaut, R. (2015). Unwelcome returns: The alienation of the new American diaspora in Salvadoran society. In D. Kanstroom \& L. Brinton (Eds.), Deported! Responding to the new deportations delirium in and beyond U.S. border (pp. 227-251). New York, NY: New York University Press.

Fránquiz, M. E., Salazar, M. D. C., \& DeNicolo, C. P. (2011). Challenging majoritarian tales: Portraits of bilingual teachers deconstructing deficit views of bilingual learners. Bilingual Research Journal, 34(3), 279-300.

Franquiz, M. E. \& Salazar, M. (2007). Ni de aqui, ni de alla: Latin@ youth crossing linguistic and cultural borders. Journal of Border Education Research, 6(2), 101-117. 
Freire P. (1970). Pedagogy of the oppressed. New York, NY: Continuum.

Gandara, P., \& Contreras, F. (2009). The Latino education crisis: The consequences of failed social policies. Cambridge, MA: Harvard University Press.

Gildersleeve, R. E., \& Hernandez, S. (2012). Producing (im)possible peoples: Policy discourse analysis, in-state resident tuition and undocumented students in American higher education. International Journal of Multicultural Education, 14(2), 1-19.

Giroux H. A. (2010). Lessons to be learned from Paulo Freire as education is being taken over by the mega rich. Retrieved from http://archive.truthout.org/lessons-be-learned-from-paulo-freire-educationis-being-taken-over-mega-rich65363

Gonzales, R. G. (2007). Wasted talent and broken dreams: The lost potential of undocumented students. Washington, D.C.: Immigration Policy Center. Retrieved from http://www.immigrationpolicy.org/special-reports/wastedtalent-and-broken-dreams-lost-potential-undocumented-students

Gonzales, R. G., \& Ruiz, A. G. (2014). Dreaming beyond the fields: Undocumented youth, rural realities and a constellation of disadvantage. Latino Studies, 12(2), 194-216.

Hooks, B. (2000). Feminist theory: From margin to center. London, UK: Pluto Press.

Hill, N. E., \& Torres, K. (2010). Negotiating the American dream: The paradox of aspirations and achievement among Latino students and engagement between their families and schools. Journal of Social Issues, 66(1), 95-112.

Knight Abowitz, K., \& Harnish, J. (2006). Contemporary discourses of citizenship. Review of Educational Research, 76(4), 653-690.

Menjívar, C. (2006a). Educational hopes, documented dreams: Guatemalan and Salvadoran immigrants' legality and educational prospects. Annals of the American Academy of Political and Social Science, 620, 177-193.

Menjívar, C. (2006b). Liminal legality: Salvadoran and Guatemalan immigrants' lives in the United States. American Journal of Sociology, 111, 999-1037.

Mydans, S. (2007). Citizens of nowhere. Retrieved from http://www.nytimes.com/2007/04/01/world/asia/01ihtstateless.1.5103819.html?_r=0

Ngai, M. M. (2014). Impossible subjects: Illegal aliens and the making of modern America. Princeton, NJ: Princeton University Press.

Nieto, S. (2009). The light in their eyes: Creating multicultural learning communities. New York, NY: Teachers College Press.

Oliverez, P. M., Chavez, M. L., Soriano, M., \& Tierney, W. G. (2006). The college and financial aid guide for $A B 540$ undocumented immigrant students. Los 
Angeles, CA: University of Southern California Center for Higher Education Policy Analysis.

Ortiz, D. D. (2013). How to achieve the "American dream" without losing your Latin soul: Bridging the gap between two worlds. Bloomington, IN: AuthorHouse.

Passel, J. S., \& Cohn, D. (2011). Unauthorized immigrant population: National and state trends, 2010. Retrieved from http://www.pewhispanic.org/2011/02/01/unauthorized-immigrantpopulation-brnational-and-state-trends-2010

Perez, Z. J. (2014). Removing barriers to higher education for undocumented students. Center for American Progress. Retrieved from http://www.luminafoundation.org/files/resources/removing-barriers-forundocumented-students.pdf

Reyes, K. B., \& Curry Rodríguez, J. E. (2012). Testimonio: Origins, terms, and resources. Equity \& Excellence in Education, 45(3), 525-538.

Robertson, E. (2008). Teacher education in a democratic society: Learning and teaching the practices of democratic participation. In M. Cochran-Smith, S. Feiman-Nemser \& D.J. McIntyre (Eds.), Handbook of Research on Teacher Education: Enduring questions in changing contests (pp. 27-44). New York, NY: Routledge Press.

Romero, T. I. (2014). Observations on history, law, and the rise of the new Jim Crow in state-level immigration law and policy for Latinos. American Quarterly, 66, 153-160.

Rumbaut, R. G. (2004). Ages, life stages, and generational cohorts: Decomposing the immigrant first and second generations in the United States. International Migration Review 38(3), 1160-1205.

Salazar, M. (2013). A humanizing pedagogy: Reinventing the principles and practice of education as a journey toward liberation. Review of Research in Education, 37(1), 121-148.

Swalwell, K. (2013). With great power comes great responsibility. Democracy and Education, 21(1), 1-11.

United Nations High Commissioner for Refugees [UNHCR]. (2012).Citizens of nowhere: Solutions for the stateless in the U.S. Retrieved

from http://www.opensocietyfoundations.org/reports/citizens-nowheresolutions-stateless-us

Valdes, G., Valencia, N., \& Levs, J. (2014). Obama vows urgent action as children make perilous illegal journey to U.S. Retrieved from http://www.cnn.com/2014/06/09/us/undocumented-children-immigrants/

Valenzuela, A., \& Brewer, C. (2011). Submerged in a neoliberal utopia: Disruption, Community Dislocation and Subtractive Citizenship. In L. Olmos, C.A. Torres, and Van Heertum, R. (Eds.), Educating the global 
citizen: In the shadow of Neoliberalism thirty years of educational reform in North America (pp. 28-43). Sharjah, UAE: Bentham Science Publishers.

Warikoo, N., \& Carter, P. (2009). Cultural explanations for racial and ethnic stratification in academic achievement: A call for a new and improved theory. Review of Educational Research, 79(1), 366-394.

Westheimer, J., \& Kahne, J. (2004). What kind of citizen? The politics of educating for democracy. American Educational Research Journal, 41(2), 237-269.

Urrieta, L. (2004). Dis-connections in "American" citizenship and the post/neocolonial: people of Mexican descent and whitestream pedagogy and curriculum. Theory \& Research in Social Education, 32(4), 433-458.

\section{Author Contact}

Maria Salazar: Maria.Salazar@du.edu

University of Denver

1999 E. Evans Ave.

Denver, Colorado 80208

U.S. A.

Lisa M. Martinez: Lisa.Martinez@du.edu

University of Denver

1999 E. Evans Ave.

Denver, Colorado 80208

U.S. A.

Debora Ortega: Debora.Ortega@du.edu

University of Denver

1999 E. Evans Ave.

Denver, Colorado 80208

U.S. A. 